\title{
Early history of petroleum exploration offshore Norway and its impact on geoscience teaching and research
}

\author{
Knut Biørlykke' \\ ${ }^{1}$ Department of Geosciences, University of Oslo. P.B. 1047, 0316 Oslo.. \\ E-mail corresponding author (Knut Bjørlykke): knut.bjorlykke@geo.uio.no
}

The Norwegian government and also the universities were unprepared for an offshore oil province. Very little information about the offshore geology was then available due to the thick cover of Quaternary and Tertiary sediments in the North Sea basins. The potential for oil and gas in the North Sea could not have been predicted before the Norwegian Continental Shelf (NCS) was opened for petroleum exploration and drilling in 1965. Statements from the Geological Survey of Norway (NGU) in 1958 that there was no potential for oil offshore Norway referred specifically to the coastal areas, where no oil has been found. The midline principle was introduced in 1964, through an agreement with the UK. A continental shelf committee led by Jens Evensen from 1963 to 1965 prepared the legal aspects and the regulations applicable for oil companies applying for licences to explore and produce oil and gas offshore Norway. A proposal for a Norwegian petroleum-related research project in 1964 was not funded and it took several years before petroleum-related teaching and research were established. After several dry wells the Ekofisk Field was discovered late 1969-early 1970, making it clear that Norway would become a significant oil-producing country. However, at that time nearly all the expertise was inside the major international oil companies and petroleum-related research at Norwegian universities and research institutes had a slow start. In 1972, Statoil and the Norwegian Petroleum Directorate (NPD) were established and also government funding for petroleumrelated teaching and research. This was met with considerable scepticism and resistance from some students and faculty and some claimed that a general education in geology would be sufficient. The University of Bergen developed a strong research group in marine geophysics and later one in petroleum geology. The need for petroleum-related teaching and research created a great challenge for the Norwegian universities. The standard was variable and the output of graduates with a professional qualification was generally too low. What we know about sedimentary basins and many fundamental geological processes is the result of petroleum prospecting and data from drilling and seismic data, contributing to Norwegian geology and general geological principles.

Keywords: Petroleum, Offshore Norway, Norwegian Oil history, Geoscience Teaching and Research, Norwegian Continental shelf

Received 22. November 2018 / Accepted 3. May 2019 / Published online 5. July 2019

\section{Introduction}

\section{Historical background, Applied geoscience in Norway}

The purpose of the present paper is to document an overview of the early history of Norwegian petroleum exploration as seen from the perspective of a petroleum geologist who has been involved in Norwegian petroleum activities as an active participant in teaching and research since the beginning. It is, however, useful also to look back at Norwegian geology before the petroleum history started, when mining geology was the main applied geological discipline. Historically, the mining industry was the most important example of applied geology where mineralogy and chemistry were crucial for understanding the properties and composition of rocks and minerals and for the production of materials and tools from stones and metals. In Norway and in

Bjørlykke, K. 2019: Early history of petroleum exploration offshore Norway and its impact on geoscience teaching and research. Norwegian Journal of Geology 99, 1-17. https://dx.doi.org/10.17850/njg99-3-2. 
much of Europe the mining industry was very important economically, technologically and scientifically. The mining academies played important roles as institutions for higher education from the $18^{\text {th }}$ century, in some cases developing into universities. The Norwegian Mining Academy at Kongsberg was established in 1757 and after a slow start it became a centre for higher education in Norway from 1780 to 1790 until a university was established in 1811. This was "Det Kongelige Fredriks Universitet," later renamed the University of Oslo (UiO).

Norway was then what now would have been called a developing country in terms of science and technology, and most of the staff at Bergseminaret and in the mining industry were foreign experts (Pedersen, 2003). The mining terminology was mostly German and the first professor was Johan Heinrich Becker from Germany. Jens Esmark (1762-1839) studied first at the University of Copenhagen and then moved to Kongsberg in 1789. He took the "Bergeksamen" (mining exam) at Kongsberg in 1791 and then studied for one year with Professor W. G. Werner in Freiburg. He then contributed to teaching at a rather advanced level in chemistry and mineralogy at the Kongsberg Bergseminar and in 1814 was the first professor to be appointed in Geology (Bergvitenskap) at the University of Oslo. (See also Gabrielsen et al., 2005).

Esmark had many interests which were not limited to disciplines directly useful in relation to mining and one of his main contributions was the discovery of evidence for glacial processes like glacial striation and for the existence of large-scale glaciations in the Quaternary (Hestmark, 2017).

At the University of Oslo (UiO), mining geology could be studied as a special discipline and the students were called "bergkandidater" up to 1913, when this education was taken over at the newly established Norges Tekniske Høgskole (NTH) in Trondheim. At UiO they obtained a degree in mining geology and engineering (Cand. min.). In the beginning, relevant jobs for those who had studied basic sciences at the universities were scarce outside the mining industry. Geology and mining subjects in some periods made up an important part of the Faculty of Science and could account for up to 50\% of the students because of the good job prospects in the Norwegian mining industry. The education in mining geology and technology was very popular, particularly in the period 1900-1913 when the Norwegian mining industry was booming. J.H.L. Vogt was appointed Professor of Metallurgy at $\mathrm{UiO}$ in 1886 and he agreed to continue his teaching and research in Trondheim when NTH (later, from 1996, NTNU) was established as a technical university in 1910. When Professor Vogt moved to Trondheim he established mining geology and engineering (at NTH) while research at the UiO focused mostly on theoretical and academic disciplines, mainly mineralogy, petrology, geochemistry, palaeontology and general geology. Prof. W.C. Brøgger played an important role, with major contributions to both palaeontology and mineralogy/petrology. In addition, Brøgger was Rector at $\mathrm{UiO}$ and for a period a Member of Parliament. Professor Victor M. Goldschmidt established an international centre at $\mathrm{UiO}$ for geochemistry before he left for Germany (Göttingen) in 1928. He succeeded in getting funding for material research, setting up Råstoff Laboratoriet, but rather limited industrial development followed as a result.

Later professors like Tom Barth, Henrich Neumann and Ivar Oftedal provided a very strong theoretical basis in geochemistry and mineralogy, as did Anatol Heintz, Leif Størmer and Gunnar Henningsmoen in palaeontology, but there were very few job prospects in these fields. Prof. Olaf Holtedahl played an important role in the area of general and regional Norwegian geology. At the University of Oslo, the focus was on what was then considered fundamental research, also in geology. From the 1960s the mining industry in Norway was in decline and did not contribute much to geological research in Norway.

The mining industry in Norway employed relatively few and there were not many other jobs for a geologist outside the universities, the Geological Survey of Norway (NGU) and the Norwegian Polar Institute. At the University of Oslo there was for the most part little interest in applied geology. From the early 1950s the Norwegian Geotechnical Institute (NGI) was located close to the University of Oslo. NGI soon became a research institution with an international reputation, but there was limited contact with respect to teaching and research. Soil science and engineering geology were not taught before Prof. Ivan Rosenqvist, with a background from NGI, started courses at $\mathrm{UiO}$ on geotechnical principles in 1964. Before then, there had been little incentive for strengthening subjects like geophysics, sedimentology and organic geochemistry at UiO.

\section{Early petroleum history}

Several books and papers have been published on Norwegian oil history, mainly written by authors without a background in geology/geophysics or technology. This includes "Norges Oljehistorie" (Kindlingstad \& Hagemann, 2002) and "Norsk Oljehistorie" (Hansen et al., 1982; Bergsager, 1984, Hanisch \& Nerheim, 1992; Nerheim, 1996; Lerøen, 2002; Johnsen, 2008; Ryggvik, 2009; Skjeldal \& Berge, 2009; Tonstad, 2010; Vislie, 2017). The emphasis in these accounts is mainly on the administrative and political aspects of the nation's oil history. This is also the case for other publications about our oil history. The contribution of geologists and engineers in oil exploration and production is not discussed in most of this literature. See also more popular presentations of the geological aspects of the oil history (Bjørlykke, 1989a, b, c, 1992, 1994; Sellevold \& Sundvor, 2001; Gabrielsen et al., 2005; Landrø, 2013). 


\section{GEOLOGIC MAP OF NORTH SEA TO ILLUSTRATE OIL \& GAS PROSPECTS}

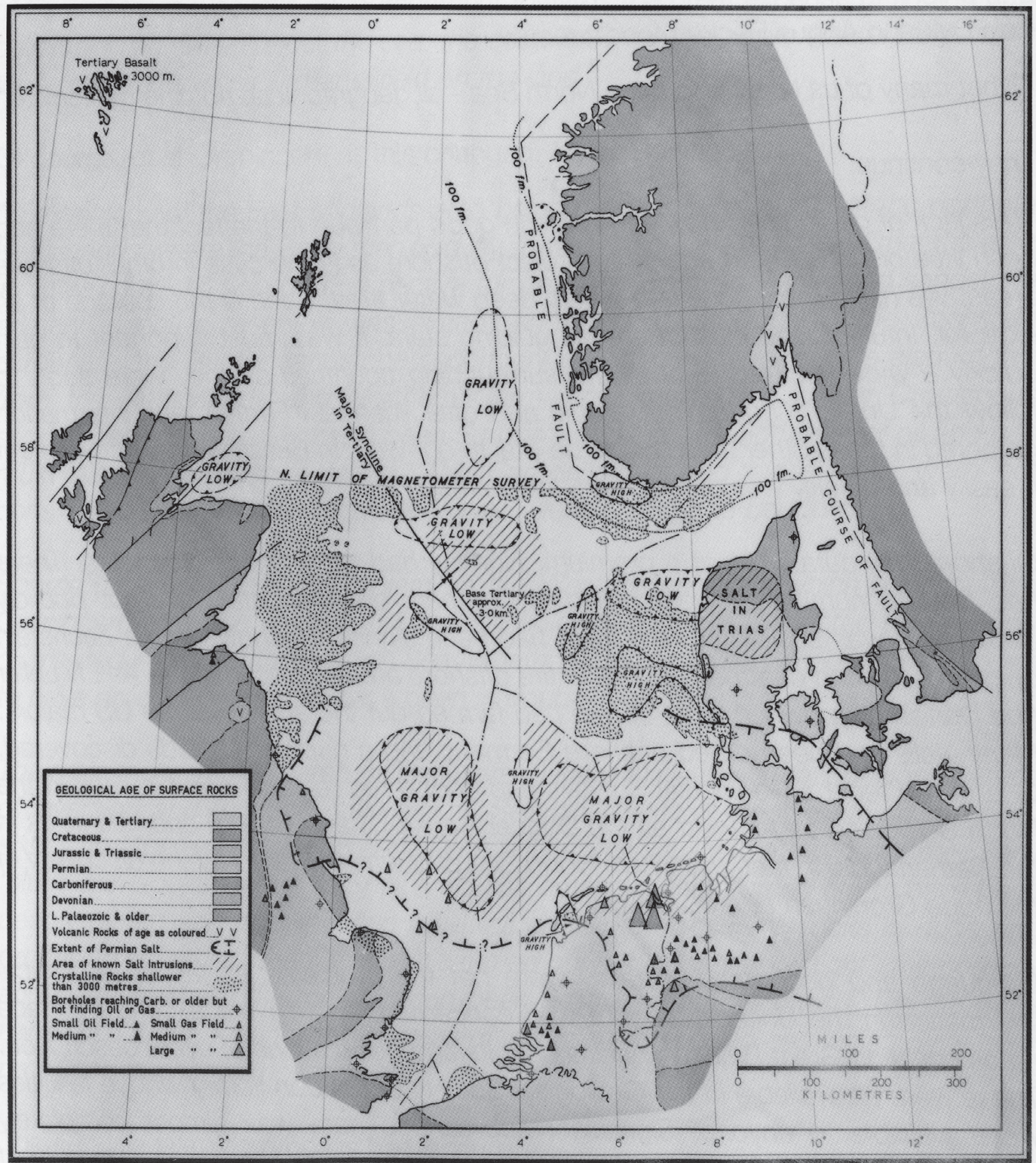

Figure 1. Early geological map of the North Sea, 1962-1963. Salt had been detected from gravity and magnetic surveys, but there was little information about North Sea rifting. This provided only a limited basis for prediction of the petroleum potential. From Moreton (1995). Reproduced with permission from The Petroleum Exploration Society of Great Britain.

The potential for oil and gas in the North Sea could not have been predicted before the Norwegian Continental Shelf (NCS) was opened for petroleum exploration in 1965. Very little information about the offshore geology was then available due to the thick cover of Quaternary and Tertiary sediments in the North Sea basin. A map from 1962-1963 shows mostly magnetic data and the distribution of evaporates (Fig. 1). 
During 1960-63, some international oil companies started to take an interest in the North Sea basin based on a possible extension of the 1958 gas discovery in Groningen. Phillips Petroleum applied in 1962 for "An oil and gas concession covering lands beneath the territorial waters of Norway, plus that portion of the continental shelf which may now or in the future belong to or be under the jurisdiction of Norway". This would have been an exclusive right to explore for oil and gas offshore Norway but fortunately this was not granted by the Norwegian Government.

The midline principle was only introduced in 1964, through an agreement with the UK driven by their eagerness to begin exploration in the North Sea. The first well offshore UK was drilled in 1965, before Norway's first well in 1966. There was no attempt from the British side to claim more North Sea territory based on the 200 $m$ depth principle. On the Norwegian side the second well discovered indications of oil which was considered non-commercial in 1967, but which became developed as the Balder field 30 years later.

After several dry wells it was only in late 1969-early 1970 that a major commercial Norwegian oil field (Ekofisk) was discovered in the Chalk when drilling for reservoirs in the deeper Permian sandstones. The Upper Cretaceous Chalk was not expected to be a good reservoir rock because of its low permeability and Phillips Petroleum tried to avoid drilling this last obligatory well, but high flow rates were discovered during drilling. It then became clear that Norway could have the potential to become a significant oil-producing country and that it would be necessary to prepare for that. However, at that time nearly all the expertise was inside the major international oil companies and data from exploration were highly confidential.

Already in the period from the 1930s petroleum geology became an advanced science based on modern chemistry, physics and several geological disciplines as shown by textbooks like Levorsen's "Geology of Petroleum" (Levorsen, 1967). Much of the research in this field was carried out within the oil companies and their research laboratories, and represented important contributions to general geological processes.

Petroleum exploration increasingly involved also offshore sedimentary basins along many continental margins, using seismic data and exploration wells. Most of what we know about the geology of both continental and oceanic crust is based on such data from oil companies. This provided a basis for modern plate tectonics which, in turn, became an important part of petroleum exploration. Its now seems strange that petroleum-related geology should be considered too specialised to be taught at all at the Norwegian universities when it involved so many geological disciplines and technologies. Internationally, particularly in the US and many parts of Europe, the oil industry employed a very large percentage of all professional geologists. The development of new geophysical methods including sequence stratigraphy contributed greatly to our understanding of fundamental processes related to the development of sedimentary sequences. Oil wells provided quantitative data on Earth history as well as on the compaction (diagenesis) affecting rock properties during burial.

What was known about the geology of Offshore

Norway before it was opened for petroleum exploration in 1965?

Norway was traditionally a hard rock country and geological research was focused on igneous/ metamorphic geology and also palaeontology and Quaternary geology from onshore Norway. In "Geology of Norway" (Holtedahl, 1960), the only reference to Mesozoic rocks is related to Andøya, North Norway. Holtedahl discusses supposed marginal faults and uplift of the land in Cenozoic time and also glacial erosion in the Skagerrak (Holtedahl, 1962). When I studied Geology at the University of Oslo (1957-1963), the geology of the North Sea and offshore Norway was hardly mentioned by my lecturers. On Svalbard, however, there was some early interest in oil in connection with the coal-bearing strata. Mesozoic sedimentary rocks were considered rather irrelevant.

Onshore drilling in Denmark in 1952-54 proved the presence of Mesozoic and Upper Palaeozoic sedimentary rocks, but did not find oil, mainly because the Upper Jurassic source rock was not mature (Sorgenfrei \& Buch, 1964; Sorgenfrei, 1969; Moreton, 1995). As part of a larger ocean drilling survey of the oceans in 1951-53, it became clear that there was a sequence of at least $4 \mathrm{~km}$ of sedimentary rocks in the North Sea. However, this was not published until 1959 (Ewing \& Ewing, 1959) and this important result was not focused on in this publication and received little attention in Norway because it was not mentioned in the title or the conclusion. Other studies in the 1950s and early 1960s also found some geophysical evidence of the outline of the structural control in the North Sea basin, but they were based on limited evidence and data (Gabrielsen \& Dore, 1995).

Petroleum exploration started early on Spitsbergen, in 1960, and oil companies including Norsk Hydro and Statoil continued exploration and drilling up to 1994 (Jakobsson, 2018; Senger et al., in press). Only traces of oil and gas were found and it is surprising that companies were willing to invest in these projects, which did not hold much prospect of finding commercial petroleum, and also considering the environmental aspects involved. Spitsbergen was, however, not a part of the NCS and had a different legislation and taxation system, compared to offshore Norway. In retrospect, it is difficult to understand to what extent these projects were based on insufficient competence or that the investments were 
made for some strategic reasons. The petroleum history of Svalbard is however outside the scope of the present paper but the reader is referred to Senger et al. (in press).

Prof. Hans Holtedahl at the University of Bergen (UiB) was trained as a marine geologist at Scripps (La Jolla, Ca, USA). He established marine geology at UiB and carried out sample dredging on the seafloor offshore western Norway (Møre). Clasts recovered from the dredging were almost exclusively of Precambrian or Caledonian metamorphic basement rocks. The conclusion drawn from this study was that offshore western Norway consisted of Quaternary sediment and moraines overlying basement rocks (Holtedahl, 1955).

Prof. Markvard Sellevold led the early geophysical surveys from 1962 and the teaching of marine geophysics at the Geophysical Observatory (Jordsjelvstasjonen, UiB). In 1962-65, Sellevold and his research group carried out seismic surveys in the Møre Banks area and offshore Mid Norway These indicated the presence of young sedimentary rocks below the Quaternary glacial sediments, thus confirming the magnetic measurements carried out by NGU in 1962 (Hanish \& Nerheim, 1992, p. 116). Seismic surveys were shot first using dynamite and with the use of airguns from 1966. Among Sellevold's first graduates in Bergen was Anders Farestveit who later played an important role in the Norwegian petroleum industry, continuing as a technical expert up to the present. Olav Eldholm and Eirik Sundvor at UiB established an important collaboration with Malik Talwani at the Lamont-Doherty Earth Observatory at Columbia, USA. Later, Eldholm and Jan Inge Faleide formed a strong marine seismic group at the University of Oslo.

NGU started airborne magnetic measurements in 1962 of the continental shelf off Mid Norway, showing depth to basement. Magnetic surveys (aerial magnetic measurements) produced by the Norwegian Geological Survey (NGU) in 1962-63 showed depth to basement. They continued this airborne geophysical mapping up to 1975 . The results clearly demonstrated that Mesozoic and younger sediments were lapping on to the basement close to the present coastline and were very important contributions to the mapping of the Continental Shelf (Ingvaldsen, 1983; Børresen \& Wale, 2008). There was limited relevant expertise in Norway on marine seismic and geology and Sellevold and Kvale at UiB started co-operation with the University of Copenhagen and Clausthal University in Germany.

A magnetic residual map was compiled by NGU in 1965, showing variable depth to basement and that Mesozoic sediments are lapping on to the present coastline. Later gravity data from the Vøring Pateau indicated sediment thicknesses of up to $5 \mathrm{~km}$ (Grønlie \& Ramberg, 1970). Gravity measurements were also used to map out salt domes like the Paarup salt dome onshore Denmark
(Ramberg \& Lind, 1968). Seismic profiles from the Geophysical Observatory (UiB) that was led by Sellevold demonstrated that the basement was found at variable, but mostly great depths and that the shelf was covered by thick Quaternary, mostly glacial, sediments and that older sediment sequences were also present (Fig. 2). Seismic investigations by Jordskjelvstasjonen mapped out the thickness of Quaternary sediments on the Norwegian continental shelf and also of the underlying Tertiary and Mesozoic sedimentary rock successions (Holtedahl \& Sellevold, 1972). These documented that the present bathymetry was a result of glacial erosion and deposition. A seismic section showed the transition from basement and into the sediments offshore Bergen. The seismic line was shot in 1967 when airguns had just replaced dynamite as signal source (Sellevold \& Sundvor, 2001). The seismic surveys were a part of the Skagerrak Project which was started by Sellevold in 1962 and funded by a NATO committee for oceanography. It also received some support from the German Research Council and NAVF. Spending money on the seismic surveys in 19621963 was criticised by the Government (Department of Industry) (NAVF report, 1981). They were of the opinion that exploration and also scientific investigations should be paid for by the petroleum industry and not by Norwegian taxpayers.

Because of the thick Quaternary cover, it was difficult to find information about the underlying sedimentary sequences in the North Sea basin. There were no oil seepages or natural oil spills on the sea floor that could indicate the presence of oil at greater depth. Statements in a book by Erik Pontoppidan in 1753 ("Det Første Forsøg på Norges Naturlige Historie"), that there should be drops of oil and bitumen in the ocean, were certainly based on a misunderstanding (Jahren \& Bjørlykke, 2005). What was observed in the ocean might be due to bioluminescence in algae (morild, It is surprising that Pontoppidan has been given credit for postulating the presence of oil in the North Sea in popular books on Norwegian petroleum history like Lerøen 2002 ("Statoil 1972-2002") and "Norges Oljehistorie" by Torbjørn Wigestrand, also in 2002 (Kindlingstad \& Hagmann, 2002). The statements from Pontoppidan have been repeated in a number of popular articles and even in articles in Teknisk Ukeblad, Norsk Skoleforum and norskoljeoggass.no (Faktasider/oljehistorie (03.01.2017)). In the Jens Evensen biography (Vislie, 2017) it is stated that Norwegian geologists did not believe in North Sea oil in contrast to what Pontoppidan understood already in 1752 !

The potential for finding oil in the North Sea had to be based on some sort of geological evidence, but this had yet to be discovered. Good seismic data were absent and results from drilling were not acquired until 1966, when a thick sedimentary sequence was proven, through the Cenozoic into the Mesozoic. When looking at a relatively recent geological map of the North Sea area and farther 


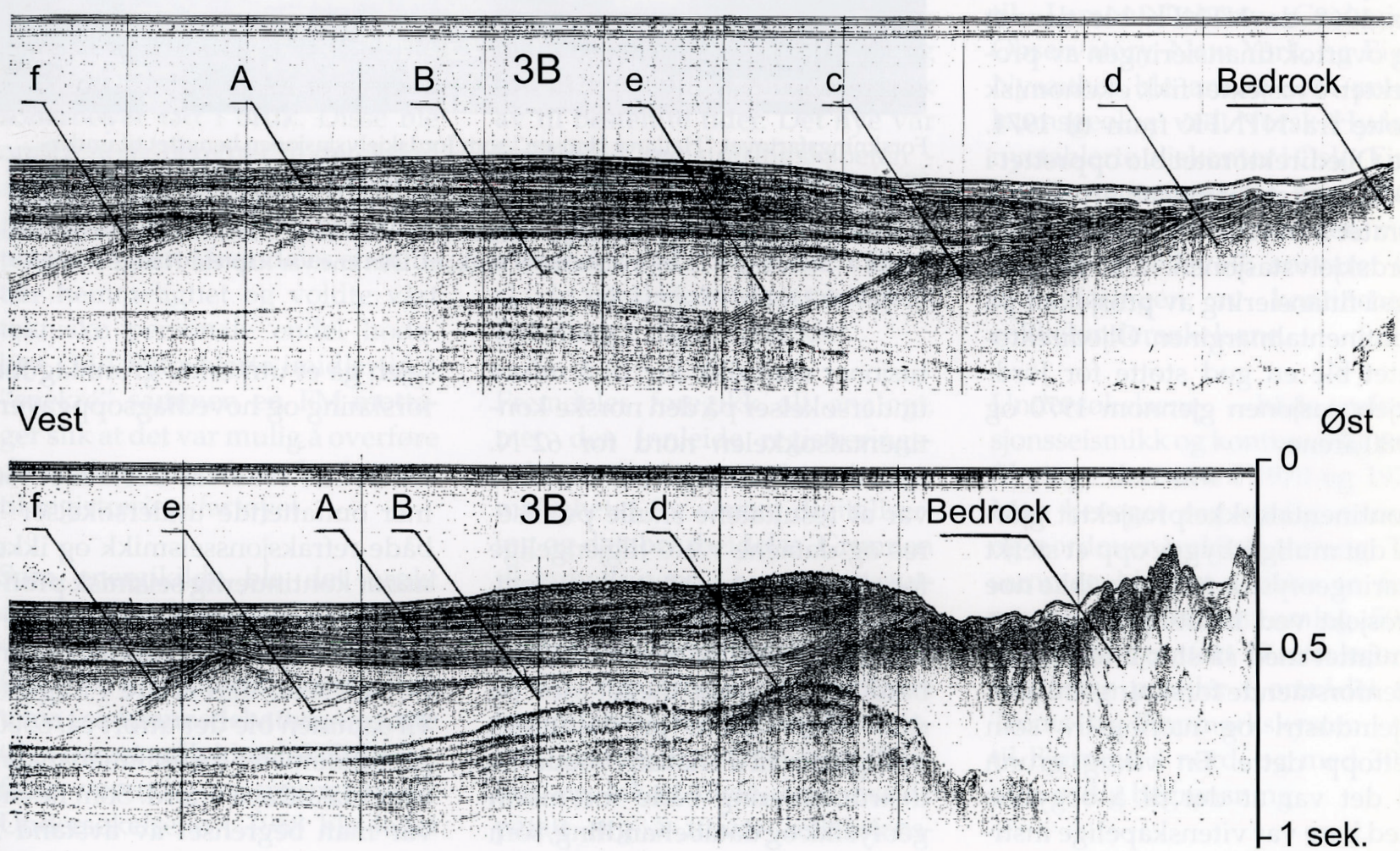

Figure 2. Seismic section showing the transition from basement into the sedimentary rocks offshore Bergen. The seismic line was shot in 1967 when airguns had just replaced dynamite as signal source. From Sellevold \& Sundvor (2001). Reproduced with permission from the Department of Earth Science, University of Bergen

north it is important to consider what was known during the early exploration from 1965 prior to advanced seismic and drilling. Only after the North Sea rift system had been mapped by seismic data could source-rock potential maturity and the potential for traps be assessed. This was also the time when the first plate-tectonic models were published.

Early maps of the geology of the North Sea (19621963) included the outline of salt deposits based on gravity measurements and magnetic data, but almost no information about the rift structures which are critical for maturation. Mesozoic sediments are found along the coastlines of countries around the North Sea like Denmark, the Netherlands and Britain and it was natural to assume that they would continue into the North Sea Basin. They included organic-rich black shales of Jurassic age, though for the most part they had not been buried deeply enough to become mature.

Petroleum exploration on the Norwegian Continental Shelf (NCS)

The history of Norwegian exploration can only be understood in the context of contemporary knowledge about the geological conditions required for petroleum systems to both form and trap oil and gas, and also with reference to the development of exploration methods. In connection with the Law of the Sea conference in Geneva in 1958, the Norwegian Foreign Office sent a letter (dated 19.02.1958) to the Geological Survey of Norway (NGU) requesting an evaluation of possible economic interests in the submarine areas outside the Norwegian coast, mainly mineral resources on or below the sea floor. The letter also pointed out that the outer extent is not defined, but referred to the limit out to $200 \mathrm{~m}$ water depth proposed by The International Law Commission ("Folkerettskommisjonen") in Geneva in 1958. If these principles should have been applied, Norway would have had a very small and narrow continental shelf because of the deep Norwegian Channel that lies parallel with the coast. The potential for oil and gas on the Norwegian shelf was not specifically mentioned by UD in this letter to NGU. In his reply on behalf of NGU, Christoffer Oftedahl wrote on short notice that he assumed that a reply was urgently required since the meeting in Geneva started yesterday (23/2). The answer was written at night and sent the next day, counter-signed by the Director Sven Føyn. This was shortly before he resigned in 1958 when it was decided that NGU should be moved from Oslo to Trondheim. He was succeeded by Harald Bjørlykke who became a member of the Continental Shelf Committee led by Jens Evensen in 1963-1965.

The focus in this letter from NGU was the potential for finding ore bodies very close to the Norwegian coast both in northern and in southern Norway (see also 
Børresen \& Wale, 2008, p. 220). This is in agreement with the then recent publication by Hans Holtedahl (1955) that concluded that at least part of the nearshore shelf below the thick Quaternary sediments is underlain by basement rocks which are a continuation of those on land. Oftedahl therefore concluded that coal and oil could be excluded. He also made a short comment where he states there is no chance of finding oil and gas along the Norwegian coast. This statement from NGU (letter from Oftedahl \& Føyn, dated 25. February 1958) has been quoted by authors of articles and books on our oil history as an example of incompetence among Norwegian geologists. It is true that NGU had very little competence in petroleum geology, but the conclusion in the letter was broadly correct, given the definition of the continental shelf which it was natural to assume at that time, i.e., restricted to the area close to the present coastline. The correct answer would have been that they had no information to support or disprove the prospects for oil offshore Norway.

If the Norwegian delegation to the Geneva meeting in 1958 had been better prepared, they could have approached NGU earlier and specified alternative definitions of the shelf so that NGU had time to prepare a more comprehensive answer. According to the Director of NGU at the time, Knut Heier (Heier, 1978), most Norwegian geologists would have made similar statements to those made by Chr. Oftedahl and Sven Føyn, based on the information then available. In many sedimentary basins we find evidence of oil based on seepage to the surface, but in the North Sea basin there were no indications of oil on the sea floor or on the surface. Up to 1966, when Norwegian petroleum exploration started and the first well was drilled, only very primitive marine seismic data were available. They could not provide much evidence of Tertiary and Mesozoic sedimentary sequences. It had, however, been demonstrated that Mesozoic sediments continued eastwards, onlapping basement rocks near the Norwegian coast (Sellevold \& Sundvor, 2005) (Fig. 2).

The success of the Norwegian oil policies has to a large extent been attributed to Jens Evensen (see Evensen, 1971) and also his younger colleagues, Nils Gulnes, Carl August Fleisher and Leif Terje Løddesøl, who were lawyers focusing on the legal and political aspects of securing the Norwegian Shelf for oil and gas exploration and production (Løddesøl, 1965). They clearly played an important role in establishing a legal framework for hydrocarbon development of the Norwegian continental shelf. The contributions from petroleum-related teaching and research to a Norwegian oil policy have, however, received less attention.

Oil in the North Sea, when could it be predicted? Up to about 1965, the geology of the Norwegian continental shelf was almost unknown, essentially because of the very thick cover of Pleistocene and
Tertiary sediments. Plate tectonics was just evolving as a new field of science, but was not accepted as a predictive tool in the study of sedimentary basins before about 1970. There was no basis for predicting the oil and gas potential of the North Sea basin offshore Norway before the 1966 well discovered a mature source rock, the Upper Jurassic Kimmeridge Shale. Few Norwegian geologists were involved in the early discussions about the potential for oil and gas in the North Sea, presumably because the lack of relevant data meant they had little to contribute.

It was known that Mesozoic sedimentary rocks onshore Denmark and England extended into the North Sea basin, but not how far these sediments continued towards Norway. There were, however, indications that such sedimentary rocks were present very close to the Norwegian coastline.

A report to the Continental Shelf Committee in 1964 from Harald Bjørlykke (Bjørlykke, 1964) (Director of NGU) points out that blocks of Jurassic rocks are found near the coastline, indicating that Mesozoic sediments extended to the Norwegian coastline, and that fragments of Cretaceous sediments (Chalk) are found in moraines on Jæren in SW Norway, suggesting that the Mesozoic sedimentary rocks are also on-lapping the southern coast of Norway. The report stated that it is probable that the Norwegian continental shelf had source rocks and a potential for oil, but that this could only be determined after drilling and more seismic data.

The first licensing round offshore Norway in 1965 opened for exploration. It was surprising that so many (278 of 346) blocks were open for bids in the first round. This may reflect the lack of experience from the government (Ministry). It was well known that the Upper Jurassic shales in onshore eastern England and Denmark were not mature, suggesting that this also could be the case in much of the North Sea basin. Fortunately, in the central part of the North Sea basin close to the midline between the British and Norwegian sectors of the shelf, late Jurassic rifting and subsidence had buried the shales deeply enough to be mature. The distribution of the Upper Jurassic Kimmeridge Clay (Draupne Fm, Mandal Fm, Spekk Fm) and its burial depth (maturation) were critical. Only after drilling the first well in 1966 in Blokk $8 / 3$, where small amounts of oil and gas were discovered, did we know that the North Sea basin actually had a sequence of Upper Jurassic mature shales with a high content of organic matter. These turned out to be the main hydrocarbon source for most of offshore Norway.

Some oil companies clearly wanted to discourage the establishment of national petroleum expertise which could develop into a national oil company. This view was expressed by the British Petroleum geologist T.F. Gaskell in an article in Aftenposten (Gaskell, 1967) (Fig. 3). He stated that oil companies were not very interested in North Sea exploration but that petroleum exploration 
Morgennummer 80 øre Tirsdag 31. oktober 1967. 108. årgang.

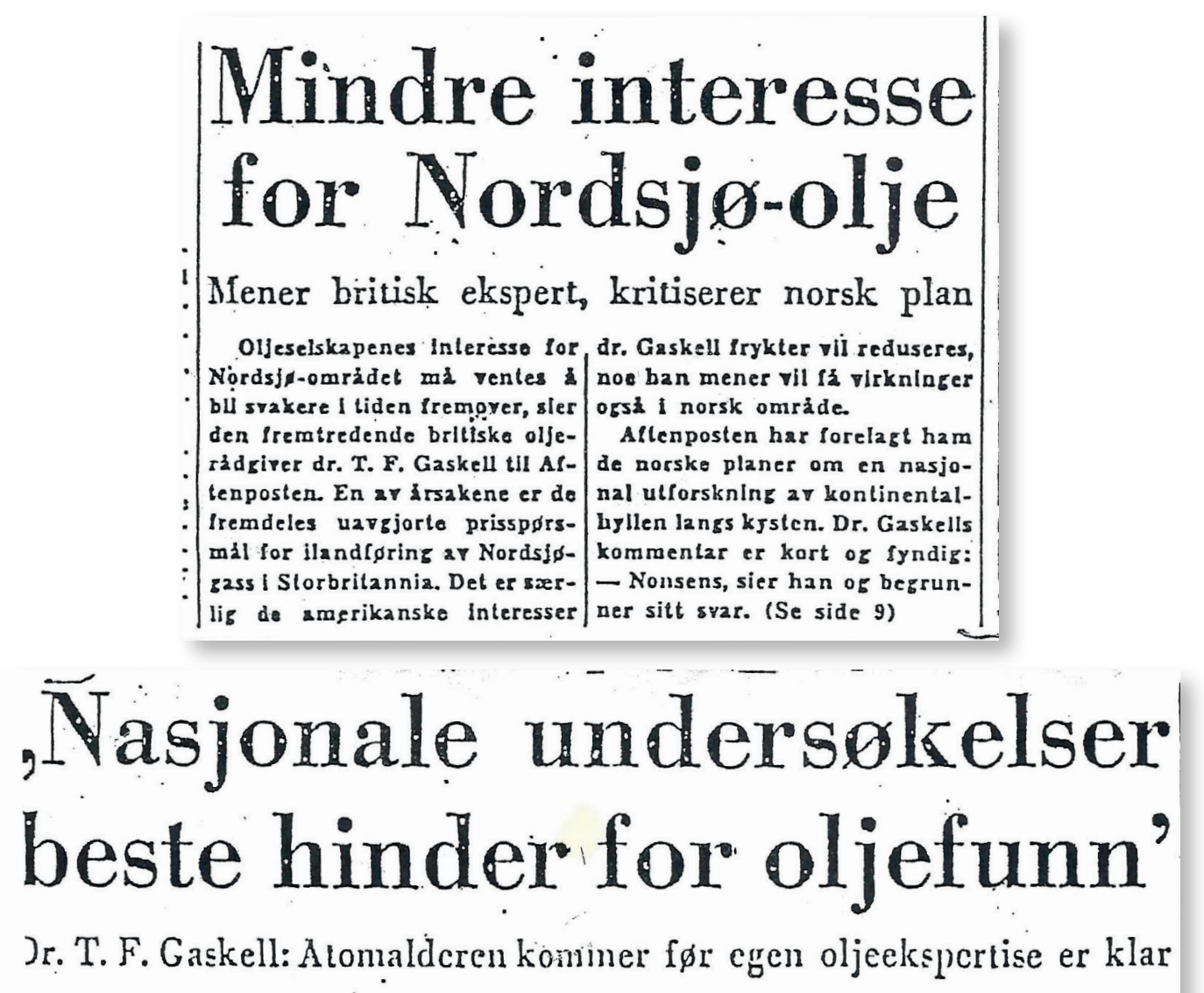

Figure 3. Aftenposten 31st October 1967. Some of the experts like Dr. T.F Gaskell (BP) from the international oil companies tried to discourage the Norwegian government from developing a national petroleum industry

should be done by the international oil companies that had the required expertise. When asked about Norwegian exploration, his answer was "Nonsense". "No country had succeeded in finding oil." There was no need to build up national petroleum expertise in Norway. He argued that by the time Norway could develop its own petroleum research and industry, we would be so far ahead in the future that we would be in the atomic age.

It was clear that international oil companies would have liked to develop petroleum resources in Norway and elsewhere without having to share these with national oil companies. Generally, the basis for being optimistic about the oil prospects in the North Sea basin was weak. Also in Norway there were some who were of the opinion that we should leave all petroleum exploration and production to the international oil companies and concentrate on the taxation. Particularly in the early stage of exploration it was argued also by government representatives in Norway that the risk involved should be carried by the international oil companies.

In the beginning, the petroleum geology of the North Sea was poorly understood and did not result in a major discovery before the Ekofisk was found late in 1969 in the Chalk. This was a major surprise because the Chalk had been considered too fine-grained with too low permeability to be a good reservoir rock. The reservoir was encountered when drilling for oil in a deeper target, the Permian (Rotliegend) sandstone. This site was located on an Upper Jurassic rift structure, where the deeply buried Upper Jurassic source rock had attained maturity. One of the first geological descriptions of the Ekofisk reservoir rock was titled "Oil from Chalk - a modern miracle!" (Scholle, 1977). Chalk was not considered to be a good reservoir rock before the development of scanning-electron microscopy and oxygen isotope analysis. This provided a better basis for predicting porosity, permeability and oil and gas potential.

Petroleum-related education and research.

How did we respond to the need for relevant expertise in Norway?

In Norway in 1958 there were about 60 professional geologists, mainly employed by the universities of Oslo, Bergen and Trondheim (NTH), NGU and The Polar Institute. This was not including mining geologists, but they were also rather few at that time. Geology 
was a narrow academic subject with limited practical applications before the oil industry. At Oslo and Bergen universities the teaching of geology was for the most part limited to basic academic geology, but at NTH (later NTNU) the focus was mainly on mining geology. The mining industry in Norway was then in decline and the companies hired mainly mining engineers rather than geologists. There were also only a few geologists involved in engineering geology linked to the building industry, roads and railways.

In 1958, very little was known about the Norwegian continental shelf. Publications on modern plate tectonics first appeared in 1964-65. In the early phase in the 1960s and early 1970s Norway had very limited expertise relating to petroleum exploration and production. It took some time (up to about 1970) before modern plate tectonics as applied to the North Sea basin (Figs. 4 \& 5) was taught at most universities. The government had to rely on what was provided by certain oil companies which were advisers for the Norwegian government.

A Continental Shelf Committee was established in 1963 and was led by Jens Evensen and his secretary Leif Terje Løddesøl and included two geologists, Prof. Anders Kvale from the University of Bergen and Harald Bjørlykke who was Director of NGU.

Evensen played an important role when Norway claimed the continental shelf to the midline between Norway and the UK in 1963. In 1963 Norway proclaimed its authority over the Norwegian Shelf "as far as the water depth would allow exploitation of natural resources" ("så langt havets dypde tillater utnyttelse av naturforekomsten, uten hensyn til de ellers gjeldene sjøgrenser, likevel ikke utover midtlinjen i forhold til andre stater"). In February 1964, Britain and Norway agreed on the midline principle dividing the territories for the North Sea exploration. Britain made no attempt to uphold the idea of a boundary defined by a $200 \mathrm{~m}$ isobath (Moreton, 1995 Hanisch \& Nerheim, 1992; Moreton, 1995; Kindlingstad \& Hagemann, 2002). Later that year Denmark also accepted this model with the midline principle which was more unfortunate for Denmark and Germany.

The exact position of the midline from the coast was not always so easy to define, because of the highly irregular shape of the Norwegian coastline. The importance of the geological rift structures in the middle of the North Sea, responsible for the deeper burial and maturation of the source rock, was unknown at that time. Several oil fields were subsequently found very close to the midline. For Britain it was important to reach an agreement quickly so that they could start exploration on their own shelf and the first well on the UK sector was drilled in late 1964. There was little time for protracted negotiations with Norway and other North Sea states, and in May 1964 the UK entered into a bilateral agreement with Norway (Glennie, 1990).
The need for Norwegian petroleum-related research Professor Chr. Oftedahl at NTH (formerly at NGU) and Professor Anders Kvale at $\mathrm{UiB}$ proposed a Norwegian research programme led by the University of Bergen on the geology of the continental shelf including aerial magnetic measurements and seismic surveys. However, the estimated cost of $900,000 \mathrm{Nkr}$ over 5 years was considered too expensive. The importance of establishing independent expertise in relation to the geology of our continental shelf and its possible petroleum resources was not appreciated in 1964-65. The key members of the Continental Shelf Committee, Jens Evensen and Leif Terje Løddesøl, both considered that geological expertise was not required (Hanisch \& Nerheim, 1992, p. 31). The geologists on the Committee, Harald Bjørlykke (director of NGU) and Prof. Anders Kvale, supported the proposed research programme and argued that it was important to develop an independent national expertise. The Norwegian Government at this time had to rely on expertise from international oil companies. Evensen and Løddesøl argued that the Committee should not get involved with research which could be linked to national prestige and reflect the geologists' own interest, according to a note from Løddesøl to Evensen dated 21 Jan, 1964 (Ryggevik, 2009, Vislie, 2017).

If the research programme proposed by Chr. Oftedahl and Anders Kvale, and supported by Harald Bjørlykke, had been funded the building of a national petroleum expertise would have begun earlier. The recruitment of qualified Norwegian geoscientists would then have had a better start, which would have benefitted the universities, oil companies and the government (represented from 1972 by the Oil Directorate (NDP)). Harald Bjørlykke and Anders Kvale did however manage to get a very important condition written into the exploration licence concession terms, namely that all data and samples from each North Sea block would become the property of the Norwegian government. Similar regulations were not introduced in other North Sea countries like the UK and Denmark. The facilities for storing core samples and cuttings were greatly improved when the Oil Directorate was established in Stavanger in 1972. This Norwegian database which included well logs and seismic data was unique and became very valuable both for further exploration and for many types of research, and became a model for other countries with petroleum resources.

In 1965, a position was advertised for a geologist in the Ministry of Industry (Industridepartementet) and Fredrik Hagemann, a hydrogeologist from NGU, was appointed. He was later followed by two geologists who had graduated from the University of Oslo (Arne Lervik and Georg Hamar). Norwegian oil policy was first led from the Department of Industry before the establishment of NPD in 1972.

In 1969 Nils Spjeldnæs was appointed professor at the University of Bergen in an attempt to establish a 


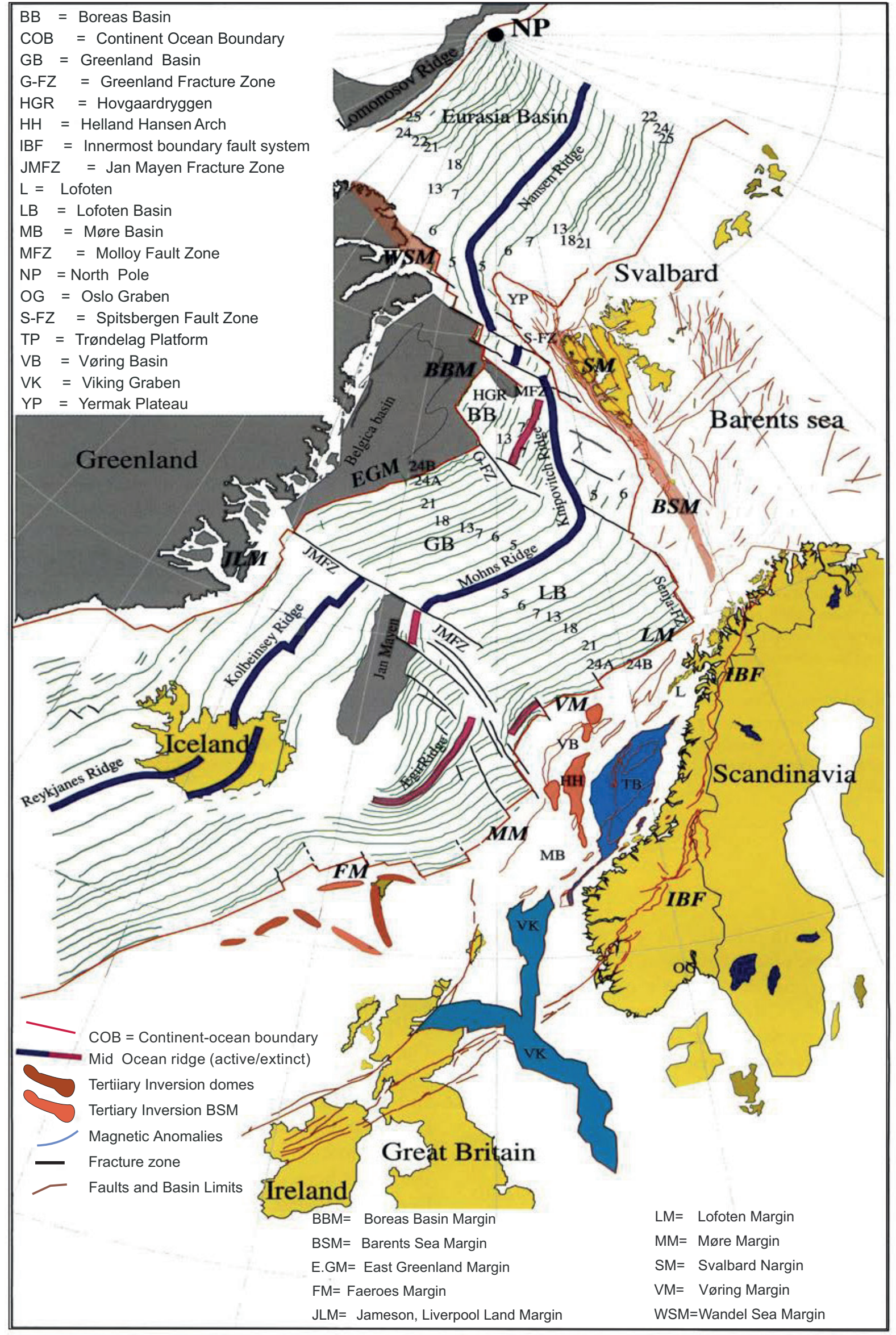

Figure 4. Geological map of the North Sea, the North Atlantic and westernmost Barents Sea. The geology of the North Sea basin and Offshore Norway was almost completely unknown when petroleum exploration started. From Mosar et al. (2002). 


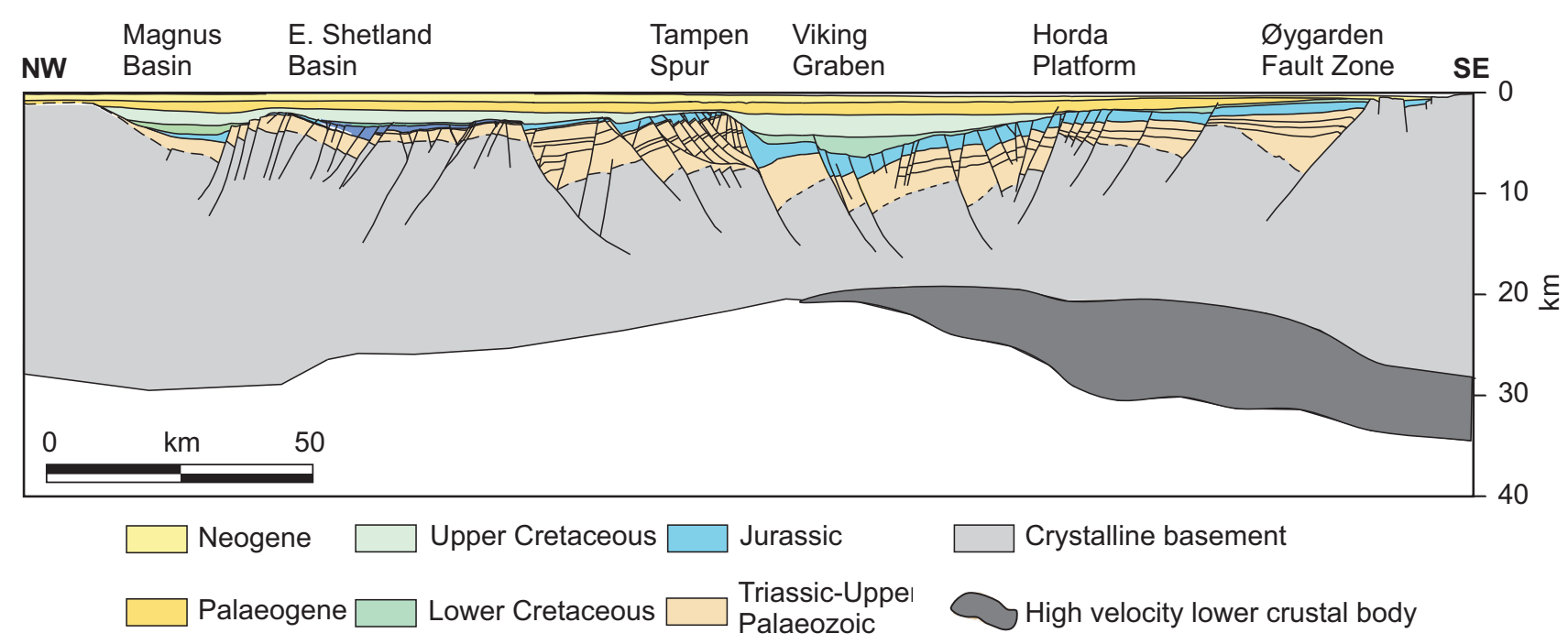

Figure 5. NW-SE cross-section through the North Sea basin. Rotated fault blocks connected Upper Jurassic source rocks with Middle Jurassic reservoir sandstones (Brent Formation). The Upper Jurassic source rock was mostly immature except along a central rift structure where it was buried more deeply. This could not have been predicted before seismic surveys and drilling were carried out after 1965. Modified from Faleide et al. (2015).

centre for petroleum geologists and geophysicists and a national centre for continental shelf research. The need for Norwegian research related to offshore Norway was stressed by Prof. Nils Spjeldnæs in an article in Aftenposten (Spjeldnæs, 1969). In 1969, NTNFK (Kontinentalsokkelkontor) was established and was led by Thorvald Mellingen until 1975 when it was moved to Trondheim and established as IKU. Spjeldnæs was also very critical of the role played by the Technological Research Council (NTNF) which from 1967 had the main responsibility for funding and organising continental shelf research. It would probably have been better if the General Research Council (NAVF) also could have played a role in continental shelf research. It quickly became clear that NTNF would be very restrictive with respect to publishing the scientific results. Due to lack of support also for his plans to develop a centre for petroleum research in Bergen, Spjeldnæs resigned his position shortly after his appointment (see Hanish \& Nerheim, 1992, p. 352-356) and became professor at the University of Aarhus in Denmark.

From 1969 to 1973, NTNF received 45 mill kr for continental shelf research. In 1965, NAVF had received only 50,000 kroner. By 1974 NTNF had a staff of 59 (37 with a university degree) and a budget of $12 \mathrm{mill} . \mathrm{kr} / \mathrm{yr}$. They also had a programme for stipends. The present author received funding for extensive visits to American universities and oil company research laboratories before he started teaching as Professor in Petroleum Geology at the University of Bergen (1976).

Special funding for petroleum education and research at Norwegian universities was first started by the Government in 1972, 6 years after petroleum exploration had begun on the Norwegian shelf. It was, however, not specified what was petroleum relevant and there were often heated discussions in the university departments about the relevance of different disciplines and the priorities of applied vs. more general and basic subjects.

When the Norwegian shelf was opened for exploration in 1965, a committee (Statens Oljeråd) was appointed, chaired by Jens Evensen and the secretary Nils Gulnes who was fresh from law school. In 1965, oil companies were invited to apply for 278 blocks south of 62 degrees North and there were 11 applications which were evaluated following the British system (Hanisch \& Nerheim, 1992). In 1968 Faruk Al-Kasim came from Iraq after having studied petroleum geology at Imperial College in London. Married to a Norwegian, he came to Norway to find a job. He made contact with the present author who was amanuensis at the Department of Geology, University of Oslo, in 1965 when Spjeldnæs became professor at Aarhus University. Knut Bjørlykke had started teaching sedimentology, stratigraphy and some petroleum geology at $\mathrm{UiO}$. He considered Al-Kasim well qualified for a university position in petroleum geology, but there was no funding at that time for the universities to develop petroleum geology. Bjørlykke then introduced him to Fredrik Hagemann at the Department of Industry in Oslo and he became a part of Hagemann's group there which in 1972 established the Oil Directorate in Stavanger (see Al-Kasim in a biography by Tonstad, 2010 and Al-Kasim 2010). In his report on Norwegian oil policy (1971), Al-Kasim gave Jens Evensen a very detailed presentation of the legal aspects of oil exploration and production in Norway and internationally. The need for petroleum-related education and research as a basis for Norwegian oil policy was, however, not mentioned.

Most university geologists in Norway had very little information about what was going on offshore Norway and it was not possible to obtain updated information 
which could be used for teaching due to confidentiality. In a textbook on the Geology of Norway by Prof. Chr. Oftedahl in 1974, there is little information about North Sea geology. The shortage of qualified geo-personnel and engineers continued and in a presentation by Al-Kasim, published by the Oil Directorate in 1981 (Al-Kasim, 1981), he estimated that Norway needed 1000 more geoscientists, 600 of which would be needed by the petroleum industry. Up to that time the total annual production of geo-personnel in all disciplines had been 58 per year and Al-Kasim recommended that this should be doubled to 120 .

\section{Teaching of Petroleum Geology at the universities}

In 1972, the Norwegian government, recognising the need to have control over its offshore resources, established the Oil Directorate, and a national oil company (Statoil) led by Arve Johnsen. This automatically generated an urgent requirement for Norwegian professionals in the petroleum sector, particularly in exploration. The first two geologists to be employed by Statoil were graduates from UiO (Arne Lervik and Georg Hamar). Special funding for petroleum-related teaching and research was made available for the universities and new positions in petroleum-related subjects were established. Oil companies were encouraged to support Norwegian universities and research institutions with teaching and geological field trips, obtaining goodwill for when they applied for offshore licences. This was a part of the successful Goodwill Agreement which for many years played a significant role in helping Norway to develop its expertise.

Bergen University (UiB) in the 1970s was a relatively young university which was easier to change and the Director Magne Lerheim supported petroleumrelated teaching and research. The larger and more established $\mathrm{UiO}$ was more difficult to change and there was considerable resistance also among geoscience faculty, who were afraid that petroleum geology could become too dominant. It was argued that a more general geological training was adequate, protecting the traditional geological disciplines.

At NTH the focus for a long time had been on mining geology producing ore geologists and engineers for the Norwegian mining industry but it proved difficult to find qualified staff to teach petroleum subjects (Hanisch \& Nerheim, 1992). This took time and the university administration appointed 4-5 professors from the international oil industry to set up teaching programmes in petroleum geology and engineering, starting in 1974. An academic career was not very tempting for most young graduates, particularly in applied subjects.

The students educated during the period 1965-1980 at Norwegian universities were far too few and many of them were also poorly qualified to meet the demands from the Norwegian oil industry, research institutions and also universities, but gradually both petroleum geology and technology reached a high standard in many disciplines although the number of graduates was for most of the time insufficient to meet the demand. As a result the oil industry also recruited both Norwegian and foreign candidates with rather weak backgrounds.

\section{Training of geologists and geophysicists, a slow start almost from scratch!}

\author{
Scepticism at universities - shortage of qualified \\ geo-personnel
}

From 1970 to 1974, Norwegian universities graduated about 40 geologists and geophysicists a year. Between 1975 and about 1980, the three main universities Bergen, Oslo and Trondheim graduated about the same number of geologists and geophysicists, totalling some 50-60 candidates annually. This increased the output to about 100 by 1990 and the output from the universities of Bergen, Oslo and Trondheim (NTH) was of the same order (Ormåsen, 1991). At that time, very few geologists and geophysicists were educated at the University of Tromsø (UiT).

At the University of Oslo, 364 students graduated in Geology during the 20 years from 1976 to 1996. Many of these had very limited qualifications with respect to petroleum subjects, but 237 were employed in petroleum-related activities. There was a shortage of petroleum geologists, the shortfall made up by a high import of geologists from other countries. Thirty-three $\mathrm{PhD}$ candidates were examined during this period, and 22 of them joined the petroleum industry.

From about 1990 the output from the universities increased, particularly at NTH where about 150 graduated annually. Still, this was only about $50 \%$ of what was required according to estimates from the Oil Directorate (Ormåsen, 1988, 1991). However, with a very large import of geologists and geophysicists from abroad, the total number in the petroleum sector in Norway totalled 1500 in 1991, with a further 300 in other sectors. In the period 1996-2000, Norwegian universities graduated 625 geoscientists: NTNU, formerly NTH (295), UiB (190), UiO (100) and UiT (40). The oil companies were encouraged to provide training such as courses and field trips to Norwegian students and graduates with different backgrounds. This was to a large extent organised through a technology agreement (Teknologiavtalene/Goodwill Agreement) whereby the oil companies received credits for courses and technological assistance which would be considered as a bonus when applying for new blocks.

It became clear at an early stage that without independent national expertise in petroleum related subjects it 
would be difficult to establish a national oil policy. This, however, took considerable time and it was difficult to recruit qualified geologists, geophysicists and engineers to government positions.

1) The petroleum industry was met with considerable scepticism (political or ideological) at some universities, among some of both the faculty and students.

2) Many of the professors and researchers where concerned that petroleum teaching and research might expand at the expense of their own disciplines.

3) Particularly at the University of Oslo many argued that they should teach basic and fundamental science and that this would provide the students with a good background for employment in the oil industry. Applied subjects could be taught on the job, it was argued.

In 1972, a national course in petroleum geology with three experienced American petroleum geologists was organised at Sanderstølen (Fig. 6). This was also the start of the Norwegian Petroleum Society.

The University of Bergen had an early start teaching marine geophysics, and graduated many candidates for research institutions and the petroleum industry. In 1972, however, the government introduced a programme to strengthen petroleum related research at Norwegian universities, specifying new university positions in relevant subjects. Professor Sellevold and his research group at Jordsjelvstasjonen (The Seismological Observatory) at UIB played a very important role, establishing a strong research group in marine geophysics in Norway (Sellevold \& Sundvor, 2005).

At NTH in Trondheim most geology students had studied mining geology and there was reluctance among the faculty to change to petroleum subjects. In 1973, following government funding for petroleum-related teaching and research, 5 new professors with a background from the oil industry were appointed by the university to start programmes in petroleum geology, geophysics and engineering. These were: J. Facer, Z.S. Wysynzki, J. Skelton, Th.Van Golf Racht and M.M. Standing. It took some time before a more permanent staff could take care of petroleum-related teaching and research. In 1974 the first students graduated as petroleum engineers at NTH in Trondheim.

At the University of Bergen, Arthur Whiteman was appointed Professor of Petroleum Geology and Ron Steel started the courses in sedimentology, both in 1972. The first academic research projects included fieldwork in the Devonian basins of western Norway and also on Spitsbergen. This provided good training in mapping sedimentary structures and interpretation of facies relationships at a time when seismic data still were limited. Fieldwork on onshore sedimentary successions was also necessary because the results could be published in regular sedimentological journals whereas offshore data were for the most part confidential.

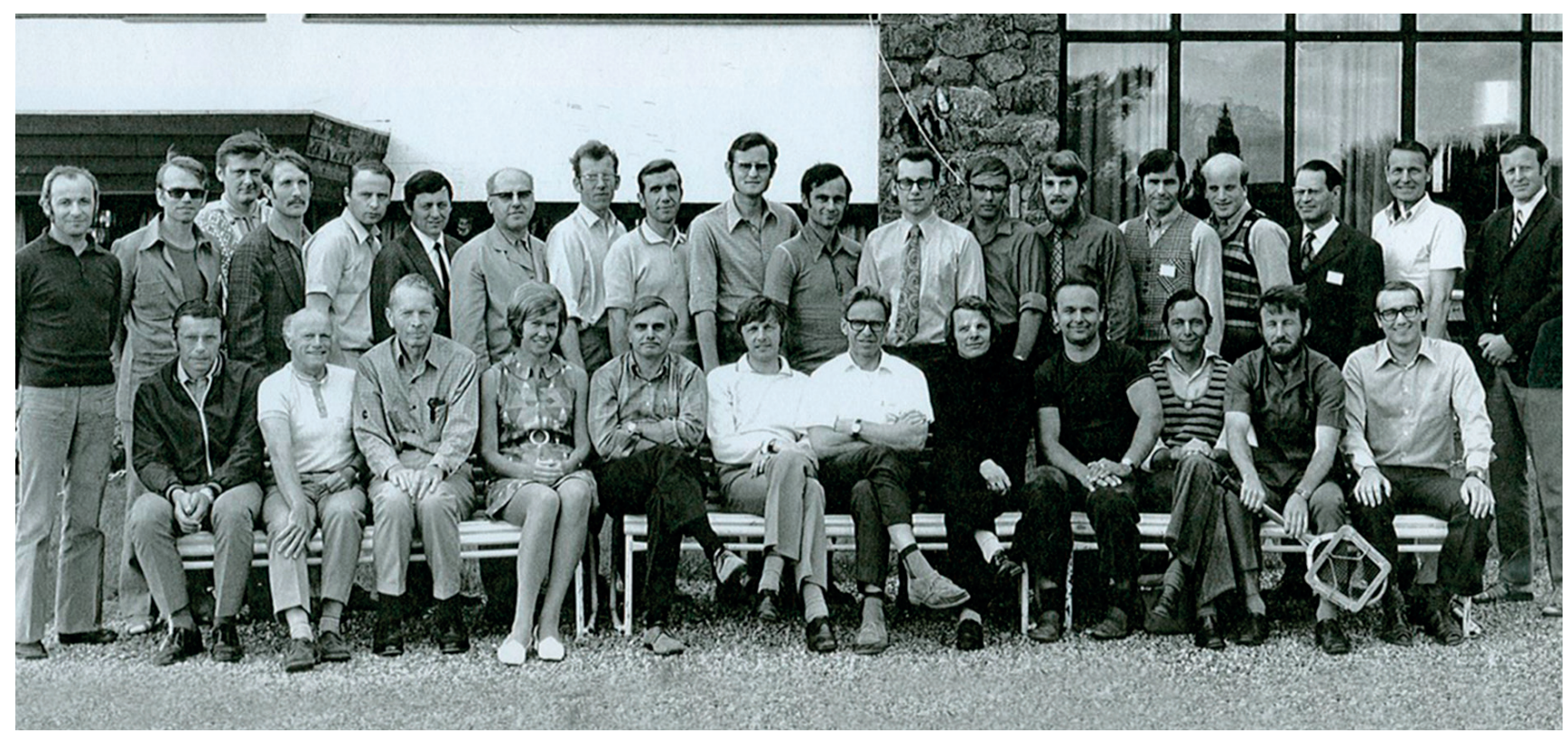

Figure 6. Participants at the first Petroleum Geology course in Norway, at Sanderstølen 1972. Teachers were Glen Visher, Park Dickey and Jerry Friedman (not present). This marked an important start in petroleum teaching in Norway. From the left: Nagy, Mellingen, Maisy, Nysater, Finstad, Brunfelt, Sellevold, Gvein, Farestveit, Bjerkeli, Torvanger, Ramberg, Dalland, Manum, Øvrebø, Sund, Henningsmoen, Winsnes, Kihle, Sundvor, Oftedal, Dickey, Slotnes, Visher, Lervik, Carstens, Kvalheim, Lauritzen, Frodesen, Bjørlykke and Grønlie. The participants have since played important roles in the oil industry as well as in teaching and research. 
Whiteman resigned after two years. He was succeeded by Knut Bjørlykke in 1976 who was the first Norwegian to be appointed Professor of Petroleum Geology. He had strong support from the University Director Magne Lerheim and also the elected university administration (Rector, Dean, etc.). Advanced courses were established in petroleum geology from 1977. In the first few years these were to a large extent based on visiting lecturers from leading research groups from both industry and academia in Britain and the USA. The courses were also initiated by the petroleum geology group at the University of Bergen from 1977. Laboratories for sediment analyses including XRD and isotope analysis were supported by Statoil. The University of Bergen also had strong research groups, particularly in marine geophysics led by Prof. Markvard Sellevold. Structural and metamorphic geology was led by Brian Sturt who was Professor of Structural Geology and as Head of the Geology Department strongly supported the petroleum geology programme at $\mathrm{UiB}$ even though this was outside his own field of research.

At the University of Oslo, extra funding for petroleum related positions and research was to a lesser extent directed to applied aspects, including in the Department of Chemistry, Physics and Mathematics. A professorship in marine geophysics, however, was established in 1972 and Olav Eldholm built up a strong research group. $\mathrm{UiO}$ was also a national centre for palaeontology including micropalaeontology and palynology.

It took some time before the importance of the Norwegian oil resources for the Norwegian economy was realised. In a report (NOU 1974:55) from an expert group led by Odd Aukrust on Norway's resources in a global context (Lied et al., 1974) only about 3 pages of the total report (203 pp.) was about oil and gas, despite the fact that Norway then had a significant oil production and great potential to become a major petroleum producer.

As it became clear that the petroleum activities on the Norwegian continental shelf would expand rapidly, the need for research and scientific competence became critical. Opinions varied greatly with respect to funding and organisation and there were no organisations which were qualified to take a leading role. In other countries the geological surveys played important roles in the administration of petroleum activities. In a hard-rock country like Norway, the Geological Survey (NGU) had limited expertise in soft-rock geology and petroleum geology; see the report about the organisation of continental shelf research by NAVF (Norwegian Science Research Council) dated 24.08.1981, marked kv/kh. Softrock geology and geophysics were therefore supported mainly by the Oil Directorate and the Research Council for Technical and Applied Research (NTNF, 1981).

\section{Academic freedom at the universities with} respect to teaching and research

Petroleum geoscience is a sophisticated field of research, and oil companies and also government institutions require a solid education and training in several disciplines including geophysics, organic geochemistry, sedimentology, structural geology, and also stratigraphy and palaeontology. A general geology degree was normally not enough. It was an ideal that the universities should be independent with limited political or administrative interference from the government and funders. University professors should have the freedom to follow their own interests with respect to research and also teaching. This was, however, not practical and budgets from the government involved some degree of steering. Also funding from industry and government institutions played an important role. Within this framework of individual departments, professors had considerable freedom with respect to research and also teaching but were limited by the funding. Samples and data from offshore Norway were stored and administrated by the Oil Directorate This provided a very important database which gradually became more accessible for university researchers.

To what extent should external funding for the universities control their internal priorities, or meet the needs of society for expertise in specific subjects? This was the subject of considerable debate which could be strongly political. As a result many students would not study petroleum subjects at the universities and this was most pronounced at the University of Tromsø, but also at the universities of Oslo and Bergen many students avoided courses relevant to petroleum. Many of them nevertheless joined oil companies or the Oil Directorate and were accepted because of the shortage of geologists. The existing academic staff at the universities was in most cases not motivated or found it difficult to change the teaching and research in the direction of petroleum geology and geophysics. This raised important principle questions. To what extent should the teaching in a university department reflect the faculty's interests and teaching competence? Or could the teaching at least to some extent reflect the needs for expertise in the society and in important industries with respect to both professional skills and student numbers?

An alternative would have been to open up the Norwegian continental shelf for the international oil companies without trying to develop our own expertise and national oil companies. We would then have been a passive receiver of petroleum tax from the major oil companies. To build up national petroleum competence required especially dedicated financial support and also technical facilities and laboratories. 


\section{Norwegian petroleum-related research}

Particularly in the early phase of petroleum exploration, up to the late 1970 s, it was very difficult to obtain samples (cores and cuttings), well logs and seismic data for research which also could be published. Kontinentalsokkelkontoret (the Continental Shelf Institute, later IKU) was a part of NTNF and was also very restrictive with respect to permission to obtain samples and data from the Norwegian offshore for researchers at the universities. Research institutions like IKU and SINTEF had access to more data, but could only to a limited extent publish the results. The Oil Directorate (NPD) had the overall responsibility to protect all data submitted by the oil companies. Meanwhile, very little funding for offshore research was channelled through NAVF. This made petroleum-related research difficult at the universities. Most geologists, including those interested in sedimentology and geophysics in Norway, therefore continued to work on onshore geology. As a result, relatively few scientific publications from offshore Norway appeared before 1975. This delayed the build-up of strong petroleum-related research groups at the universities. When the Continental Shelf Institute based in Oslo was established as IKU in Trondheim in 1975, new staff had to be recruited from a market where well-qualified geologists were in high demand both in Norway and abroad.

Research institutes like SINTEF, IKU and IFE (Institute for Energy Research) could produce confidential reports and thus were less dependent on open scientific publications. Gradually, the Norwegian offshore became more mature as more blocks were allocated to many of the larger oil companies and it became easier for university research groups to gain access to samples and data which could be published. In the late 1970s and during the 1980s there was an impressive expansion in petroleum-related research in Norway funded by the oil companies and the research council. In the space of 15-20 years Norwegian research groups were able to play a leading role in several disciplines both in petroleum engineering and in petroleum-related geology and geophysics. This provided a basis on which many companies, including consulting companies, were established in Norway. In a NTNF report from 1986 (Anonymous, 1986), about 50 experts in different fields contributed, but only 3 of these were from Norwegian universities and a very large percentage were from outside Norway. There was still a shortage of wellqualified Norwegian geologists and geophysicists and as a result a very large percentage was recruited from abroad (Hanisch \& Nerheim, 1992, p. 269).
Impact of Norwegian oil industry on Earth science research and technology

Petroleum exploration and production has increased our fundamental knowledge about geological processes. The North Sea basin contains a nearly complete sequence of Upper Palaeozoic, Mesozoic, Palaeogene and Neogene sedimentary rocks. The development of new geophysical methods and also sequence stratigraphy, sedimentology and diagenesis contributed greatly to our understanding of fundamental processes related to basin development.

Research on the properties of sandstones and shales became critical because of their potential role as reservoir rocks, cap rocks and source rocks. A large number of wells have been drilled offshore Norway and cores, cuttings and seismic and log data have been stored by the NPD. This database is of great value for further exploration and also for further research.

From being a small and narrow academic subject with relatively few practical applications, geology became an important profession employing 5-6000 geologists and geophysicists, not only in the oil industry, but also other fields. Oil production on the Norwegian Shelf increased during the 1980s and 1990s (Schreiner, 1982) and there was a discussion among the economists as to how to invest the oil revenues, which resulted in establishing the Norwegian Oil Fund (Schreiner, 1995). Production peaked in 2002 at about 30,000 barrels/day. Since then oil production has declined, but gas production has increased, maintaining a high total hydrocarbon production.

The petroleum industry in Norway has been a major factor in the Norwegian economy and energy situation despite varying oil prices (Gabrielsen \& Grue, 2012). Environmental problems and major oil spills have been limited, and major environmental damage due to oil exploration and production has not been documented. Applied petroleum-related research and developments have found applications in several fields in engineering and in technology related to environmental problems. In recent years environmental geology and storage of $\mathrm{CO}_{2}$ have become important areas of research.

A sedimentary basin like that in the North Sea makes it possible to study sediments from deposition to burial to great depth, measuring rock properties from seismic and well data as a function of overburden stress, temperature and other variables. Much of what we consider to be fundamental and academic geology is the result of very important contributions from applied research aimed at solving practical problems. Petroleum-related research has also focused on rather fundamental geological processes providing large resources and data to many universities and has been an important factor in the employment of geoscience graduates. 


\section{Conclusions}

The presence or absence of oil and gas in the North Sea basin and other parts of offshore Norway could not have been predicted prior to the acquisition of seismic and drilling data on a large scale after 1965. The thick cover of Quaternary and Tertiary sediments and the absence of oil seeps to the surface (sea floor) had given no indication of the presence of hydrocarbons. A statement made by NGU in connection with the Law of the Sea conference in Geneva in 1958 that there was no possibility of finding oil on the Norwegian continental shelf was made before the legal extent of the NCS had been defined, and referred only to the nearshore areas where, indeed, no oil has been found. The present definition of the NCS was only made in 1964, through agreement with the UK government.

When the Norwegian continental shelf was opened for petroleum exploration in 1965, Norway had almost no expertise in petroleum geology and had to rely on expertise from the major international oil companies. A proposal for funding new research programmes in petroleum geology through the Research Council (NAVF) already in 1964 was turned down by the government. The value of independent national expertise as a basis for a national oil policy was not sufficiently appreciated. Later continental shelf research was funded through NTNF.

There was considerable resistance against teaching petroleum-related subjects at the University of Oslo and particularly at the University of Tromsø. This was partly due to scepticism towards the petroleum industry, but also because of a fear that the introduction of new subjects could expand at the expense of existing disciplines. It therefore took a long time before positions in the oil industry, research institutions and universities could be filled with qualified geo-personnel from Norway. Starting in 1972 Norwegian universities received extra funding for petroleum-related teaching programmes, but they were unable to produce enough candidates to meet the requirements of government institutions like the Oil Directorate, research institutions, universities and oil companies.

The petroleum industry has had an enormous impact on the Norwegian economy, but also on teaching and research in petroleum-related science and technology and also in other fields. This has strongly influenced science and technology in other areas in Norway. Environmental studies aimed at reducing pollution, and also engineering geology, have benefitted from science and technology from the oil industry. Without the petroleum industry, geology and geophysics would have been small disciplines in Norway with limited employment opportunities.
Acknowledgements. I would like to thank colleges for reading and commenting on different versions of this manuscript. This includes Jens Jahren, Per Arne Bjørkum, Per Aagaard, Nils Roll-Hansen, Ivar Ramberg, Johan Petter Nystuen, Snorre Olaussen, Roy Gabrielsen, Jenø Nagy, Nils Martin Hanken and Adrian Read. Thanks are also due to constructive comments from the reviewers Paul Nadeau and Kim Senger.

\section{References}

Al-Kasim, F. 1981: Behovet for geofagekspertise og geoforskning innen petroleumsektoren i Norge. Lecture, Norwegian Geological Society winter meeting, 5 January, Stavanger, Norway, p. 11.

Al-Kasim, F. 2010 Managing Oil Resources: The Norwegian Model. National Council for Culture, Arts, and Literature, Alam al-Maarifa Series, No 373, 424 pp.

Anonymous, 1986: Petroleum Technologies towards the 1990's. Research and Development for the Norwegian Industry. Royal Norwegian Council for Scientific and Industrial Research Report, 93 pp.

Bergsager, E. 1984: The Norwegian Continental Shelf Discoveries and Related Research Challengers. Norwegian Petroleum Directorate Contributions 21, 34 pp.

Bjørlykke, H. 1964: Om mulighetene for oljeforekomster i den norske kontinentalplattform. Note to The Norwegian Research Council for Science and the Humanities (NAVF). Published in NGU Nytt 17 (1972), 4-10.

Bjørlykke, K. 1989: Geofagene inn i oljealderen. Populorvitenskapelig magasin 4, 42- 46.

Bjørlykke, K. 1991: Utforskningen av den Norske Kontinentalsokkel gjennom 30 år. Lecture at the Norwegian Academy of Science, Yearbook 1989, p. 121-124.

Bjørlykke, K. 1992: Norsk kontinentalsokkel-forskning og oljeindustrien. Norsk vitenskapshistorisk Selskap, Årbok, 1989-1991, 105-123.

Børresen, A.K. \& Wale, A. 2008: Kartleggerne. Norges Geologisk Undersøkelse 1958-2008. NGU, 351 pp.

Evensen, J. 1971: Oversikt over oljepolitiske spørsmål - bl.a. på bakgrunn av utenlands oljelovgivning og utenlandsk konsesjonspolitikk. Betenkning utarbeidet etter oppdrag fra Industridepartementet, 120 pp.

Ewing, J. \& Ewing, M. 1959: Seismic refraction measurements in the Atlantic Ocean basin, in the Mediterranean Sea, on the MidAtlantic Ridge and in the Norwegian Sea. Bulletin Geological Society of America 70, 291-318. https://doi.org/10.1130/0016-7606(1959)70[291:SMITAO]2.0.CO;2.

Faleide, J.I., Bjørlykke, K. \& Gabrielsen, R. 2015: Geology of the Norwegian Continental Shelf. In K. Bjørlykke (ed.): Petroleum Geoscience, From Sedimentary Environments to Rock Physics, Springer Verlag, Berlin. pp. 603-637. https://doi.org/10.1007/978-3-642-34132-8_25.

Gabrielsen, R.H., Bruton, D.L., Bryhni, I. \& Ramberg, I.B. 2005: On the shoulders of giants: Musings on the history of geoscience in Norway. Norwegian Journal of Geology 85, 3-22.

Gabrielsen, R.H. \& Doré, A.G. 1995: The history of tectonic models on the Norwegian continental shelf. In Hanslien, S. (ed.): Petroleum Exploration and Exploitation in Norway - Past Experiences and Future Challenges. A Celebration of 25 Years, Norwegian Petroleum Society Special Publication 4, pp. 341-375. https://doi.org/10.1016/S0928-8937(06)80050-0.

Gabrielsen, R.H. \& Grue, J. 2012: Norwegian Energy Policy in Context of the Global Energy Situation. The Norwegian Academy of Science and Letters, $129 \mathrm{pp}$.

Gaskell, T.F. 1967: Nasjonale undersøkelser beste hinder for oljefunn. Aftenposten, 31 October 1967. 
Glennie, K.W. 1990: Introduction to the Petroleum Geology of the North Sea, $3^{\text {rd }}$ edition. Blackwell Scientific Publications, Oxford. 401 pp.

Grønlie, G. \& Ramberg, I.B. 1970: Gravity indications of deep sedimentary basins below the Norwegian Continental Shelf and the Vøring Plateau. Norwegian Journal of Geology 50, 375-391.

Hanisch, T.J. \& Nerheim, G. 1992: Norsk Oljehistorie - fra Vantro til Overmot. Norwegian Petroleum Society Bind 1, Leseselskapet, 523 pp.

Hansen, T.B., Lange, O.J., Lavik, H. \& Olsen, W.H. 1982: Oljeeventyret, Norsk Oljevirksomhet $i$ Tekst og Bilder. Universitetsforlaget, Oslo, 160 pp.

Heier, K. 1978: Heier har ordet: om det å lage prognoser. NGU Nytt, 3-5.

Hestmark, G. 2017: Istidens Oppdager. Jens Esmark, Pioneren i Norges Fjellverden. Kagge Forlag, Oslo, 690 pp.

Holtedahl, H. 1955: On the Norwegian Continental Terrace, primarily outside Møre og Romsdal - its geomorphology and sediments. University of Bergen, Yearbook 1955, pp. 1-200.

Holtedahl, H. \& Sellevold, M. 1972: Notes on the influence of glaciation on the Norwegian continental shelf bordering on the Norwegian Sea. Royal Norwegian Council for Scientific and Industrial Research, Continental Shelf Project Publication 6, 31-38.

Holtedahl, O. 1960: Geology of Norway. Geological Survey of Norway Series 208. 1-540.

Holtedahl, O. 1962: Echo soundings in the Skagerrak, with remarks on the geomorphology. Geological Survey of Norway, Yearbook 1962, 139-160.

Ingvaldsen, K. 1983: Norges Geologiske Undersøkelse 1958-1983, Geological Survey of Norway Series 385, 1-115.

Jahren, J. \& Bjørlykke, K. 2005: Olje i Nordsjøen Anno 1752. Myten om Erik Pontoppidan. Geo 8, 14-16.

Jakobsson, K. 2018: A history of exploration offshore Norway: the Barents Sea. Geological Society of London, Special Publications 465, 219-241. https://doi.org/10.1144/SP465.18.

Johnsen, A. 2008: Norges Evige Rikdom. Oljen, Gassen og Petrokronene. Aschehoug \& Co, 415 pp.

Kindlingstad, T. \& Hagmann, F. 2002: Norges Oljehistorie. Wigestrand, 343 pp.

Landrø, M. 2013: Geofysisk kartlegging en norsk suksess. Teknisk Ukeblad 52, 52.

Lerøen, B.V. 2002: Dråper av Svart Gull. Statoil, 1972-2002. Statoil, 264 pp.

Levorsen, A.I. 1967: Geology of Petroleum. W.H. Freeman \& Co., San Francisco, 724 pp.

Lied, F., Aukrust, O., Breirem, K., Baalsrud, K., Eide, W.B., Rosenqvist, I. \& Sætesdal, G. 1974: Norges ressurssituasjon i global sammenheng. Norges Offentlige Utredninger 55, 1-209.

Løddesøl, L. 1965: Norsk Rett om Oljeutvinning. Lov og Rett, 285 pp.

Moreton, R. 1995: Tales from Early UK Oil Exploration 1960-1989. Petroleum Exploration Society of Great Britain, 30th Anniversary Book, 142 pp.

Mosar, J., Eide, E.A., Osmundsen, P.T., Sommaruga, A. \& Torsvik, T. 2002: Greenland-Norway separation: A geodynamic model for the North Atlantic. Norwegian Journal of Geology 82, 281-298.

NAVF Utredningsinstitutt 1981: Kontinentalsokkelforskning. P-K Trekk fra Utviklingen. 24 August 81. KV/tkh. 43 pp.

Nerheim, G. 1996: Norsk Oljehistorie. En gassnasjon blir til - Bind 2. Leseselskapet, $311 \mathrm{pp}$.

Ormåsen, E. 1988: Behovet for geofagekspertise innen oljerelatert industri. The Norwegian Petroleum Directorate Report, 4 pp.

Ormåsen, E. 1991: Behov for Geologer og Geofysikere i Norge. The Norwegian Petroleum Directorate Contribution 30, 9 pp.

Pedersen, B. 2003: Det Kongelige Norske Bergseminar i Kongsberg. Kjemi 04, 19-25.

Pontoppidan, E. 1753: Det første forsøg paa Norges naturlige historie, forestillende dette kongerigets luft, grund, fjelde, vande, metaller, steen-arter, dyr, fugle, fiske og omsider indbyggernes naturel, samt sadvaner og levemaade. De Berlingske Arvingers Bogtrykkerie, København, 464 pp. https://doi.org/10.5962/bhl.title.70332.

Ramberg, I.B. \& Lind, G. 1968: Gravity movements on the Paarup salt dome. Bulletin of the Geological Society of Denmark 18, 221-240.

Regjeringen 2019: Norsk Oljehistorie på 5 minutter. Last update 20.03.2019.

https://www.regjeringen.no/no/tema/energi/olje-og-gass/norskoljehistorie-pa-5-minutter/id440538/.

Ryggvik, H. 2009: Til Siste Drape. Oljens Politiske Økonomi. Aschehoug, $415 \mathrm{pp}$.

Scholle, P.A. 1977: Chalk diagenesis and its relation to petroleum exploration; oil from chalks, a modern miracle? American Association of Petroleum Geologists Bulletin 61, 982-1009.

https://doi.org/10.1306/C1EA43B5-16C9-11D7-8645000102C1865D.

Schreiner, P. 1982: Norsk ressurspolitikk: Utvinningstempoet for norske petroleumsressurser. Norsk Petroleumsforening, 136 pp.

Schreiner, P. 1995: Utvinningstempoet for Norske Petroleumsressurser. The Norwegian Petroleum Society, Report 341/95, 136 pp.

Sellevoll, M.A. \& Sundvor, E. 2001: Jordskjelvstasjonen. Institutt for den faste jords fysikk gjennom ett århundre. University of Bergen, 250 pp.

Sellevoll, M.A. \& Sundvor, E. 2005: Historia om Jordskjelvstasjonen i Bergen - og korleis Norge vart ein oljenasjon. Naturen 129, 114131.

Senger, K., Bugmans, P., Grundvåg, S.A., Jochmann, M., Nøttvedt, A., Olaussen, O., Skotte, A. \& Smyral-Sikoral, A. in press: Petroleum exploration and research drilling 1 onshore Svalbard: a historical perspective. Nowegeian Journal of Geology 99.

Skjeldal, G. \& Berge, U. 2009: Feber, Historia om Norsk Olje og Gass. Cappelen Damm, 348 pp.

Sorgenfrei, T. 1969: A review of petroleum developments in Scandinavia. In Heppe, P.W (ed.): The Exploration for Petroleum in Europe and North Africa. Institute of Petroleum, London, pp. 191203.

Sorgenfrei, T. \& Buch. A. 1964: Deep tests in Denmark 1935-1959. Geological Society of Denmark 36, 1-146 pp.

Spjeldnæs, N. 1969: Norsk innsats på kontinentalsokkelen. Aftenposten 7 July 1969.

Teknisk Ukeblad 2013: Norge sakker akterut på oljeforskning. Last update 04.12.2013.

https://www.tu.no/artikler/norge-sakker-akterut-paoljeforskning/233177.

Tonstad, P.L. 2010: Fauouk-Al Kasim. Hemligheten bak det norske oljeevenyyret. Landbruskforlaget, $191 \mathrm{pp}$.

Vislie, I. 2017: Jens Evensen, Havet, Oljen og Retten. Orkana, Stamsund. $639 \mathrm{pp}$. 